SILVA, A. G.; COSTA, E.; ZOZ, T.; BINOTTI, F. F. S. Micrometeorological characterization of protected environments for plant production.Revista de Agricultura Neotropical, Cassilândia-MS, v. 8, n. 4, e6177, out./dez. $2021 . \quad$ ISSN $2358-6303 . \quad$ DOI: https://doi.org/10.32404/rean.v8i4.6177.

\title{
Micrometeorological characterization of protected environments for plant production
}

\author{
Abimael Gomes da Silva', Edilson Costa ${ }^{2}$, Tiago Zoz ${ }^{2}$, Flávio Ferreira da Silva Binotti \\ ${ }^{1}$ Universidade Estadual Paulista "Júlio de Mesquita Filho", Campus de Ilha Solteira, Ilha Solteira, São Paulo, Brasil. E-mail: \\ maeldruida@hotmail.com \\ ${ }^{2}$ Universidade Estadual de Mato Grosso do Sul, Unidade Universitária de Cassilândia, Cassilândia, Mato Grosso do Sul, Brasil. E- \\ mail: edilson.costa@uems.br, zoz@uems.br,binotti@uems.br
}

Received: 11/05/2021; Accepted: 18/08/2021.

\section{ABSTRACT}

This study evaluates the influence of the four seasons and twelve months of the year on the micrometeorological variables of global solar radiation, air temperature, and relative air humidity in different protected environments for plant production. The protected environment types and the characteristics of the shade screen modify the indoor air temperature. This environment provides greater relative humidity. The global solar radiation percentages in the environments were: full sun (100\%); black screen with 30\% shading (47.3\%); greenhouse with LDPE + 22-30\% shading screen under the film (38.1\%); aluminized screen with $35 \%$ shading $(36.9 \%)$ and greenhouse with LDPE + $42-50 \%$ shading screen under the film (26.9\%). The micrometeorological conditions of environments such as air temperature, relative air humidity, and global solar radiation in the seasons of year are similar to the behavior verified in the monthly test. Air temperatures and global solar radiation formed two distinct groups, with the spring and summer seasons being considered one group and autumn and winter another group. The summer and autumn periods showed the highest relative humidity compared to the winter and spring periods, with a low percentage of air humidity. Seasons in the study region are not as well defined as those in the northern hemisphere.

Keywords: Solar radiation; Temperature; Relative humidity; Seasons.

\section{Caracterização micrometeorológica de ambientes protegidos para a produção vegetal}

\section{RESUMO}

Objetivou-se com o presente estudo avaliar a influência das quatro estações e dos doze meses do ano nas variáveis micrometeorológicas de radiação solar global, temperatura do ar e umidade relativa do ar em diferentes ambientes protegidos para a produção vegetal. Os tipos de ambiente protegido bem como as características do tipo e cor tela de sombreamento modificam a temperatura do ar interna. $\mathrm{O}$ ambiente protegido propicia maior umidade relativa do ar. As porcentagens de radiação solar global nos ambientes foram: pleno sol (100\%); telado preto de $30 \%$ sombreamento (47,3\%); estufa com PEBD + tela de $22-30 \%$ de sombreamento sob o filme $(38,1 \%)$; telado de tela aluminizada de $35 \%$ de sombreamento $(36,9 \%$ ) e estufa com PEBD + tela de $42-50 \%$ de sombreamento sob o filme $(26,9 \%)$. As condições micrometeorológicas de temperaturas do ar, umidades relativas do ar e radiação solar global dos ambientes nas estações do ano são similares ao comportamento verificado no ensaio mensalmente. As temperaturas do ar e radiação solar global formaram dois grupos distintos, sendo dessa forma as estações do ano de primavera e verão considerados um grupo e outono e inverno constituindo outro grupo. $\mathrm{O}$ verão e outono foram os períodos com maior umidade relativa do ar em contraste com os períodos de inverno e primavera, com baixa porcentagem de umidade do ar. As estações do ano na região de estudo não são bem definidas como as do hemisfério norte..

Palavras-chave: Radiação solar; Temperatura; Umidade Relativa; Estações do ano. 


\section{Introduction}

The monitoring and characterization of behavior of micrometeorological variables in a protected environment depending on the covering material, type of environment, period of the year, and production location, aim to verify the fluctuations of these variables and the possible actions, whether automated or no, with mechanical or manual activation, for better plant environment management, avoiding or reducing stresses on the installed crop and providing greater crop yield (Costa et al., 2020). In some Brazilian locations, the behavior of micrometeorological variables in protected environments with different configurations and the relationship between variables and their behavioral difference between indoor and outdoor environments were studied.

These studies often involved energy balance, radiation and/or mass balance, such as the environmental modification caused by low perforated polyethylene tunnels in lettuce growth (Buriol et al., 1993a), the meteorological elements in a plastic greenhouse in Pelotas-RS (Camacho et al, 1995), the protected cultivation and microclimatic aspects (Sentelhas and Santos, 1995), the energy balance in pepper plants under protected and field cultivation (Cunha et al., 2001), the energy balance in the cucumber crop in a natural and protected environment (Galvani and Escobedo, 2001), the radiation balance and heat flux in the soil in a natural and protected environment with cucumber cultivation (Galvani et al., 2001), the estimation of the latent heat flux by the energy balance in pepper protected cultivation (Cunha et al., 2002), the micrometeorological alterations caused by the plastic greenhouse and its effects on the pepper crop growth and production (Cunha and Escobedo, 2003 ), the use of meshes and shading in a protected environment and on the growth and commercial production of Gerbera jamesonii (Guiselini et al., 2004a), the effect of the protected environment cultivated with melon on the meteorological elements and its relationship with external conditions (Vásquez et al., 2005), the microclimate of vineyards cultivated under plastic cover and full sun (Lulu e Pedro Júnior, 2006), the microclimatic characterization of coffee trees cultivated under shading mesh and in full sun (Morais et al., 2007), the study of microclimate simulations in greenhouses aiming at the acclimatization of micropropagated banana plantlets cv Grande Naine (Scaranari et al., 2008), micrometeorological changes in vineyards by using plastic covers (Cardoso et al., 2008), the management of solar radiation coverage of protected environments and its effects on gerbera production (Guiselini et al., 2010), models for estimating micrometeorological elements in a protected environment (Costa et al., 2011), the efficiency of heat-reflective and shading screens in a screen-like protected environment under high temperatures (Rampazzo et al., 2014), agricultural screens as an undercover in the cultivation of hydroponic lettuce (Sales et al., 2014), the use of thermoreflective screen in protected environments for tomato cultivation (Ferrari and Leal, 2015), solar radiation and air temperature in a protected environment (Rebouças et al., 2015) and the monitoring of micrometeorological variables in different protected environments in the winter period ( Paula et al., 2017).

Chronologically, studies involving solar radiation and luminosity in protected environments addressed aspects such as the relationship between photosynthetically active radiation and global radiation (Assis and Mendez, 1989), the effect of plastic greenhouse cover on solar radiation (Farias et al., 1993a), and the solar radiation transmissivity of lowdensity polyethylene used in greenhouses (Buriol et al., 1995). Some other researchers assessed photosynthetically active radiation and its relationship with global solar radiation in a canopy of alfalfa, according to the leaf area index (França et al., 1997), the radiation balance in snap bean crops with and without polyethylene covering (Souza and Escobedo, 1997), the effect of different types of coverage, in mini-greenhouses, in the attenuation of solar radiation and light (Sentelhas et al., 1998), and the albedo and the radiation balance estimates in snap beans under a plastic cover and external environment (Souza et al., 1999). Other issues like the radiation balance and energy of lettuce cultivation in a polyethylene greenhouse (Frisina and Escobedo, 1999), the transmissivity of solar radiation in greenhouses covered with blue and transparent PVC films (Sentelhas et al., 1999), the efficiency of the use of photosynthetically active radiation by tomato crop in different environments (Radin et al., 2003), tomato morphological changes in response to reduced solar radiation in plastic greenhouse environments (Reisser Júnior et al., 2003), and the use of meshes and shading in protected environments and their effect on global and photosynthetically active solar radiation (Guiselini et al., 2004b), were also studied. Aspects like changes in the radiation balance in a protected environment with light-diffusing polyethylene cover (Sousa et al., 2005), solar radiation in protected environments cultivated with tomato in the summer-autumn seasons of Rio Grande do Sul (Beckmann et al., 2006), and the ratio between photosynthetically active radiation and global radiation in greenhouse tomato cultivation (Steidle Neto et al., 2008) were presented. Furthermore, luminosity in protected cultivation 
environments (Santos et al., 2010), radiometric measurements in greenhouses with plastic cover in the Campinas-SP region (Costa and Leal, 2011), and components of solar radiation in tomato cultivation under protected environment conditions (Reis et al., 2012) were also widely investigated.

As for radiation and luminosity, several other works involved the temperature and relative humidity of the air. The subjects covered the modification in the minimum air temperature caused by low-density transparent polyethylene greenhouses (Buriol et al., 1993b), changes in temperature and relative humidity caused by the use of plastic greenhouses (Farias et al., 1993b), and changes in soil temperature caused by low-density transparent polyethylene greenhouses in Santa Maria, RS (Schneider et al., al., 1993).

Topics such as the relative air humidity modification of the use and management of the plastic greenhouse (Buriol et al., 2000), the vertical and horizontal distribution of air temperatures in protected environments (Furlan and Folegatti, 2002), and the behavior of air temperature under greenhouse conditions under cultivation (Silva et al., 2003) were studied. Simulation of temperature and relative humidity inside a plastic greenhouse (Costa et al., 2004), the use of meshes and shading in a protected environment and its effect on the temperature and humidity of the air (Guiselini and Sentelhas, 2004), changes in temperature and relative humidity in a protected environment with light-diffusing polyethylene cover (Sousa et al., 2005), along with the air and soil temperature in protected cultivation environments (Santos et al., 2010), and the changes in air temperature through screens on the sides of protected environments cultivated with tomato (Duarte et al., 2011) were explored.

Given the above, this study evaluates the influence of different periods, namely the twelve months of the year and the four seasons, on the micrometeorological variables of global solar radiation, air temperature, and relative air humidity in different protected environments for plant production in the region of Cassilândia, Mato Grosso do Sul.

\section{Material and Methods}

The studies were conducted at the State University of Mato Grosso do Sul - UEMS, University Unit of Cassilândia, located at $19^{\circ} 07^{\prime} 21^{\prime \prime} \mathrm{S}$ latitude, 5143'15" $\mathrm{W}$ longitude, and altitude of $516 \mathrm{~m}$, in the period from September 2017 to September 2018. According to the Köppen climate classification, the region has Rainy Tropical Climate (Aw-type) with rainy summer and dry winter (winter precipitation less than $60 \mathrm{~mm}$ ).
Two tests were performed (T): T1) comparison of micrometeorological variables of 4 protected environments and an external environment, in a splitplot overtime scheme for 12 months in a monthly frequency (5 environments x 12 months). The design was made in randomized blocks of 5 consecutive days each, totaling 6 blocks per month; T2) comparison of micrometeorological variables of 4 protected environments and an external environment during the 4 seasons of the year (spring, summer, autumn, and winter), in a split-plot in time scheme ( 5 environments $\mathrm{x} 4$ seasons of the year). This test was also arranged in randomized blocks of 10 consecutive days each, totaling 9 blocks per season.

Four protected environments were used: two agricultural screenhouse and two agricultural greenhouses with dimensions of 18.0 × $8.0\left(144 \mathrm{~m}^{2}\right)$ with the gravel-covered floor. The greenhouses had a ceiling height of $4.0 \mathrm{~m}$ and roofs of $3.5 \mathrm{~m}$, and the external environment. They were identified from A1) to A5). A1 was an agricultural greenhouse covered with low-density polyethylene film (LDPE) light diffuser and anti-drip, with zenith opening sealed with $30 \%$ white screen, side black screen, and front $30 \%$ closed shading $90^{\circ}$ and LuxiNet ${ }^{\circledR}$ movable $42 / 50 \%$ aluminized heat-reflective screen under LDPE film. A2, same as A1, but with $22 / 30 \%$ moving screen under LDPE film; A3) agricultural screen sealed with an aluminized thermo-reflective screen with $35 \%$ shading, closed at 45 degrees. A4), same as A3 but with black monofilament screen with $30 \%$ shading and A5) outdoor environment (Full Sun).

During the period from 09/21/2017 to $09 / 20 / 2018$, hourly averages of air temperature $\left(\mathrm{T}^{\circ} \mathrm{C}\right)$, relative air humidity (RH\%), and global solar radiation (GR) were collected every day from meteorological stations model E4000 (Irriplus Scientific Equipment) installed in the geometric center of each protected environment. External data were obtained from station A742 Cassilândia (INMET). For the E1 test, the data were divided into 12 months, and for the E2 test, the collected data were distributed over the periods from $09 / 21 / 2017$ to $12 / 21 / 2017$ (Spring), $12 / 22 / 2017$ to $03 / 21 / 2018$ (Summer), 03/22/2018 to $06 / 21 / 2018$ (Autumn), 06/22/2018 to 09/20/2018 (Winter).

The E4000 stations performed the monitoring and collection, closing the averages of the variables every hour. For the temperature and relative air humidity, 24-hour averages were used, and for global solar radiation, the averages from 9:00 am to 4:00 pm (Brasília time) were employed. The experimental design was done in split plots over time, with the main plot being the environments (protected and outdoor) and the subplots the 12 months and the four seasons 
for the E1 and E2 tests, respectively. Data were subjected to analysis of variance, and when significant, the Fisher test (LSD) at $0.5 \%$ was applied.

\section{Results and Discussion}

In the test 1 , there was no interaction between environments and months of the year in this experiment (p-value > 0.05), making it possible to assess the influence of each factor separately. The months of the year, as well as the cultivation environments, influenced significantly ( $p$-value $<0.01)$ the variables analyzed within each protected environment (Table 1).

The non-interaction between factors (environments $\mathrm{x}$ months of the year) verified for all variables studied (Table 1) shows that they are independent. This finding means that the behavior of the environment is independent of the variation (absence or presence) of the months of the year and vice versa. Therefore, the study of factors separately is valid in this case (Perecin and Cargnelutti Filho, 2008). It was observed in the micrometeorological variables that types of environments, with their respective types of shading promoted by the different roofing materials, and the months of the year, were able to influence air temperature, relative air humidity, and global solar radiation (Table 2).

Regardless of the month of the year, the temperatures of the outdoor air and protected environments with less shading (30\% screen and 22-30\%) screen greenhouse were higher than the temperatures of more shaded environments $(35 \%$ screen and 42- screen greenhouse. $50 \%$ ). In more shaded environments (screen $35 \%$ and greenhouse with a $42-50 \%$ screen), the air temperature was 4.8 and $3.8 \%$ lower than the external temperature, respectively. Also, when comparing the two greenhouses, the temperature in the greenhouse with higher shading $(42-50 \%)$ screen was $3.2 \%$ smaller than in the greenhouse with less shading (22-30\%) screen. It shows that the shading intensity interferes with this variable behavior inside more shaded environments, minimizing the thermal effect (Table 2).

Table 1. Analysis of variance with the significance of the F-test for air temperatures $\left({ }^{\circ} \mathrm{C}\right)$, relative air humidity $(\%)$, and global solar radiation $\left(\mathrm{Wm}^{-2}\right)$ in the environments and months of the year.

\begin{tabular}{lccc}
\hline Source of variation & Air Temperature & Relative Air Humidity & Global Solar Radiation \\
\hline Environments (E) & $* *$ & $* *$ & $* *$ \\
Months of the year (M) & $* *$ & $* *$ & $\mathrm{~ns}$ \\
E x M & $\mathrm{ns}$ & 12.75 & 16.43 \\
CV 1 $(\%)$ & 6.98 & 15.90 & 16.88 \\
CV 2 $(\%)$ & 6.00 & $\mathrm{~ns}$ \\
\hline
\end{tabular}

$\mathrm{CV} 1$ = Coefficient of Variation 1 relative to the plots; CV $2=$ Coefficient of Variation 2 relative to sub-plots. ** $=$ significant at $1 \%$; ns = not significant.

Table 2. Air temperatures $\left({ }^{\circ} \mathrm{C}\right)$, relative air humidity $(\%)$ and global solar radiation $\left(\mathrm{W} \mathrm{m}^{-2}\right)$ in environments and months of the year

\begin{tabular}{lccc}
\hline Environments & Air Temperature $\left({ }^{\circ} \mathrm{C}\right)$ & Relative Air Humidity $(\%)$ & Global Solar Radiation $\left(\mathrm{W} \mathrm{m}{ }^{-2}\right)$ \\
\hline Full sun & $24.82 \mathrm{~A}$ & $62.84 \mathrm{~B}$ & $586.41 \mathrm{~A}$ \\
Black screen 30\% & $24.50 \mathrm{~A}$ & $70.92 \mathrm{~A}$ & $277.46 \mathrm{~B}$ \\
Greenhouse 22-30\% & $24.66 \mathrm{~A}$ & $68.54 \mathrm{~A}$ & $223.56 \mathrm{C}$ \\
Aluminized 35\% & $23.63 \mathrm{~B}$ & $68.91 \mathrm{~A}$ & $216.55 \mathrm{C}$ \\
Greenhouse 42-50\% & $23.88 \mathrm{~B}$ & $69.44 \mathrm{~A}$ & $157.86 \mathrm{D}$ \\
\hline Months & Air Temperature & Relative Air Humidity $(\%)$ & Global Solar Radiation $\left.(\mathrm{W} \mathrm{m})^{-2}\right)$ \\
\hline January & $26.27 \mathrm{~A}$ & $73.11 \mathrm{ABC}$ & $311.33 \mathrm{~A}$ \\
February & $24.97 \mathrm{~B}$ & $78.04 \mathrm{~A}$ & $302.96 \mathrm{~A}$ \\
March & $26.02 \mathrm{~A}$ & $76.08 \mathrm{AB}$ & $310.74 \mathrm{~A}$ \\
April & $23.35 \mathrm{C}$ & $75.7 \mathrm{AB}$ & $289.1 \mathrm{AB}$ \\
May & $21.91 \mathrm{D}$ & $72.49 \mathrm{BC}$ & $273.69 \mathrm{C}$ \\
June & $22.31 \mathrm{D}$ & $65.7 \mathrm{DE}$ & $252.35 \mathrm{BC}$ \\
July & $22.45 \mathrm{D}$ & $58.24 \mathrm{FG}$ & $270.25 \mathrm{BC}$ \\
August & $23.63 \mathrm{C}$ & $53.91 \mathrm{G}$ & $287.55 \mathrm{AB}$ \\
September & $24.61 \mathrm{~B}$ & $60.38 \mathrm{EF}$ & $286.58 \mathrm{AB}$ \\
October & $26.04 \mathrm{~A}$ & $61.59 \mathrm{EF}$ & $310.52 \mathrm{~A}$ \\
November & $24.91 \mathrm{~B}$ & $69.14 \mathrm{CD}$ & $302.98 \mathrm{~A}$ \\
December & $25.14 \mathrm{~B}$ & $73.2 \mathrm{ABC}$ & $310.36 \mathrm{~A}$
\end{tabular}

Means in the same column for each variable, followed by equal letters, do not differ from each other, at the $1 \%$ level by the LSD test. 
The annual average temperature of the greenhouse with $42-50 \%$ screen under the film was $3.8 \%\left(0.94{ }^{\circ} \mathrm{C}\right)$ lower than the outside temperature (Table 2). It is verified that the thermo-reflective screen with $42-50 \%$ shading under the film reflected part of the radiation. The zenith opening that reduced the greenhouse effect provided conditions for reducing the internal temperature in the environment. In a low tunnel greenhouse, an increase of $1.2{ }^{\circ} \mathrm{C}$ in the internal temperature was observed (Buriol et al., 1995) and in a greenhouse with just a milky film, with milky film and aluminized screen under the film and black screen under the film, both screens with $50 \%$ of shading, increases in temperatures of 6,3 , and $3{ }^{\circ} \mathrm{C}$, respectively, compared to the external temperature were verified (Guiselini et al., 2004a).

In a greenhouse covered with a low-density polyethylene film (LDPE) and a 22-30\% screen under the film, a higher air temperature was observed than in the heat-reflective aluminized screen with $35 \%$ shading, on average $4.2 \%$ higher (Table 2), despite having no significant differences in global solar radiation for these two environments (Table 2). The greenhouse effect caused by LDPE promoted greater thermal energy accumulation and higher air temperature than in the aluminized screen. Even though the greenhouse has a zenith opening in the ridge, the $35 \%$ thermo-reflective aluminized screen allows greater sun rays reflection in the screened environment, lowering the air temperature.

In the tomato cultivation in a pampeana greenhouse, ceiling height of $2.0 \mathrm{~m}$ and height of the ridge of $3.5 \mathrm{~m}$, covered with LDPE of 100 micrometers, the use of citros or clarite lateral screen provided an increase of $0.4{ }^{\circ} \mathrm{C}$ compared to the environment without a screen (Duarte et al., 2011). This shows that the side screens make it difficult to exchange air between the internal and external environments and raise the environment temperature.

From April to August, the lowest air temperatures were verified (Table 2; Figure 1) due to the lower intensities of solar radiation caused by the sun's movement over this period (Table 2). This months' lower temperatures are natural due to the environments' geographical location. In this period, solar radiation intensity decreases with the zenith angle formed between the solar and vertical rays of the place.

The relative humidity of the air in the protected environments was higher than in the external environment (Table 2), on average about 6.6\% higher. These results agree with those obtained by Rampazzo et al. (2014), who found a $5.1 \%$ increase. This increase in the relative humidity inside the protected environments is associated with the irrigations that occurred throughout the year in the various experiments carried out. Also, the protected environments retain a greater amount of water vapor in their interior due to shading.

In the current work, the relative humidity of the aluminized screen with $35 \%$ shading and the black screen with $30 \%$ shading were 6.1 and $8.1 \%$ higher than the external environment. These results agree with those obtained by Rampazzo et al. (2014), who found an increase of 5.3 and $5.2 \%$, respectively.

The relative air humidity inside the environments remained at higher levels $(69.45 \%)$ than the outside environment $(62.84 \%)$ (Table 2). Irrigation throughout the experiments and the lesser loss of moisture from the protected environment promoted by the screens or by the lower ventilation rate favored cultivation on substrates and plant growth.

From June to October, the lowest relative air humidity was verified (Table 2; Figure 1) due to the region's lower rainfall occurring during these months. However, the irrigations and the screens of the protected environments provided higher relative humidity than in the external environment.

The lowest solar radiation was obtained inside the greenhouse with $42-50 \%$ shading screen under the plastic film of the roof, lower than all other environments, followed by the greenhouse covered with low-density polyethylene film (LDPE) and screen. 22$30 \%$ under the film and by the heat-reflecting aluminized screen of $35 \%$ shading that did not differ from each other, but both were lower than that observed in the black screen of $30 \%$ shading, and all protected environments presented lower radiation than the external radiation (Table 2 ).

Global solar radiation was $38.1 \%$ from the outside inside the greenhouse with $22-30 \%$ screen and $26.9 \%$ in the $42-50 \%$ screen with shading under the plastic film (Table 2). It is observed that the use of shading screens under the polyethylene film significantly reduces solar radiation inside the greenhouses because in an oven with a 100-micrometer film and without a screen under the film, $78 \%$ was obtained in the high tunnel type (Camacho et al. al., 1995), 93\% in the chapel type (Farias et al., 1993) and 73\% in the low tunnel (Buriol et al., 1995). In an oven covered with a milky film and an aluminized screen under the film, $11 \%$ of the external radiation was obtained, and with a black screen $7 \%$, both screens with $50 \%$ shading (Guiselini et al., 2004b).

In the present study and the literature, the film thickness $(100$ or $150 \mu \mathrm{m}$ ), the film color (milky or transparent), and the use of a screen under the film directly influence the availability of radiation within the protected environment and the possible types of cultivation that can be adopted. Therefore, in every crop to be implemented in shaded environments, attention must be paid to the best ambiance in conjunction with 
the species to be cultivated, reduce micrometeorological stresses, and avoid possible plant stagnation.

It is observed that the use of shading screens under the polyethylene film significantly reduces solar radiation inside the greenhouses, because in a greenhouse with a $100 \mu \mathrm{m}$ film and without a screen under the film, 78\% was obtained in the high tunnel type (Camacho et al. al., 1995), 93\% in the chapel type (Farias et al., 1993) and $73 \%$ in the low tunnel (Buriol et al., 1995). In a greenhouse covered with a milky film and aluminized screen under the film, $11 \%$ of the external radiation was obtained, and with a black screen $7 \%$, both screens with $50 \%$ shading (Guiselini et al., 2004b). Film color and its use in conjunction with shading screens, the film's aging, and the accumulation of dust particles decrease the solar radiation transmissivity to the environment inside (Buriol et al., 1995). These factors should be observed in the implantation and conduction of cultivation in a protected environment.

The lowest radiation intensities were observed in May, June, and July (Table 2; Figure 2). This occurrence of lower radiation intensity in these months was due to the geographical location of the environments and the sun's movement with a greater zenithal angle (formed between the sun's rays and the vertical of the place).

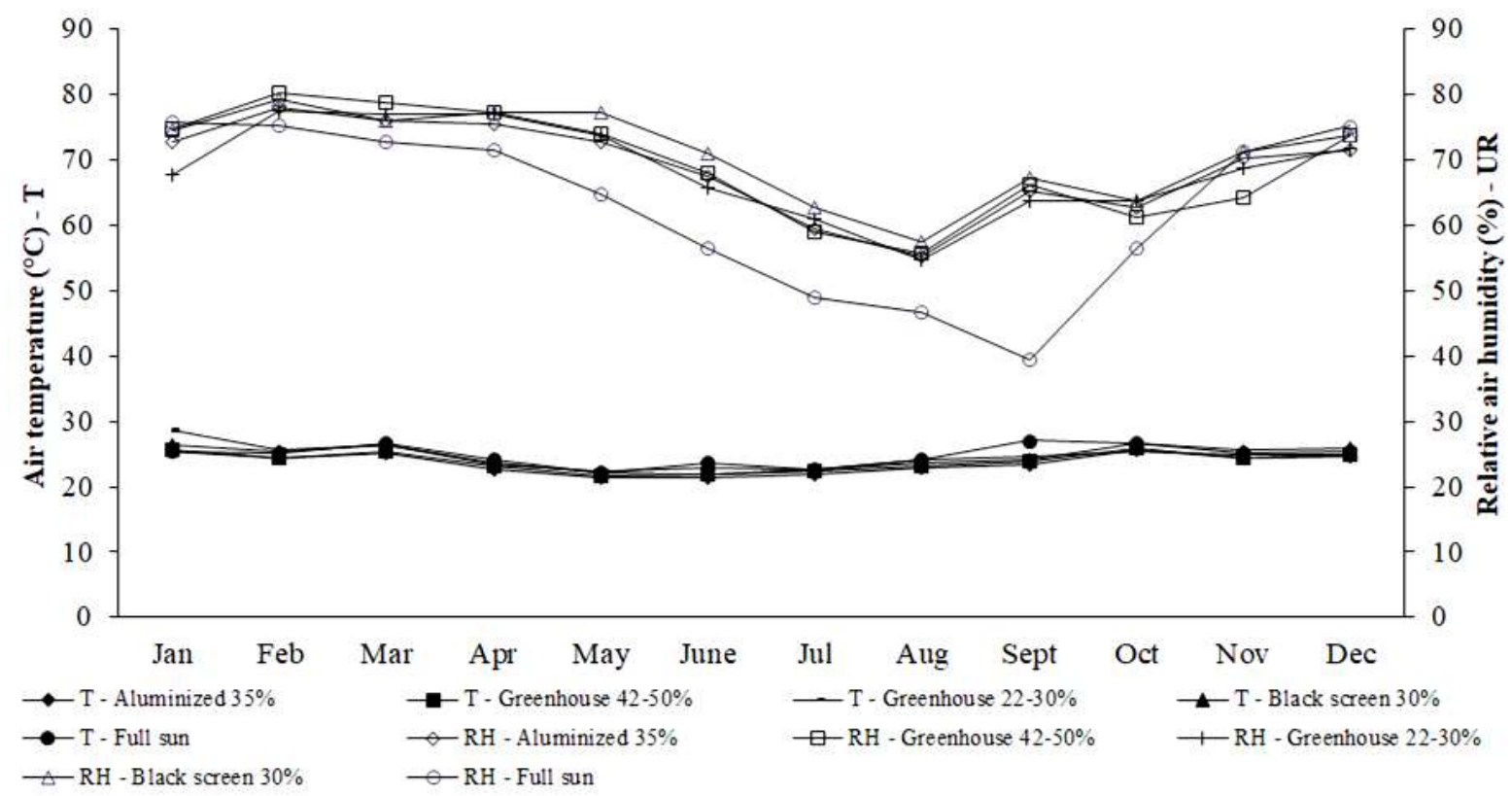

Figure 1. Monthly air temperature $\left({ }^{\circ} \mathrm{C}\right)$ and relative air humidity $(\%)$ in protected and outdoor environments.

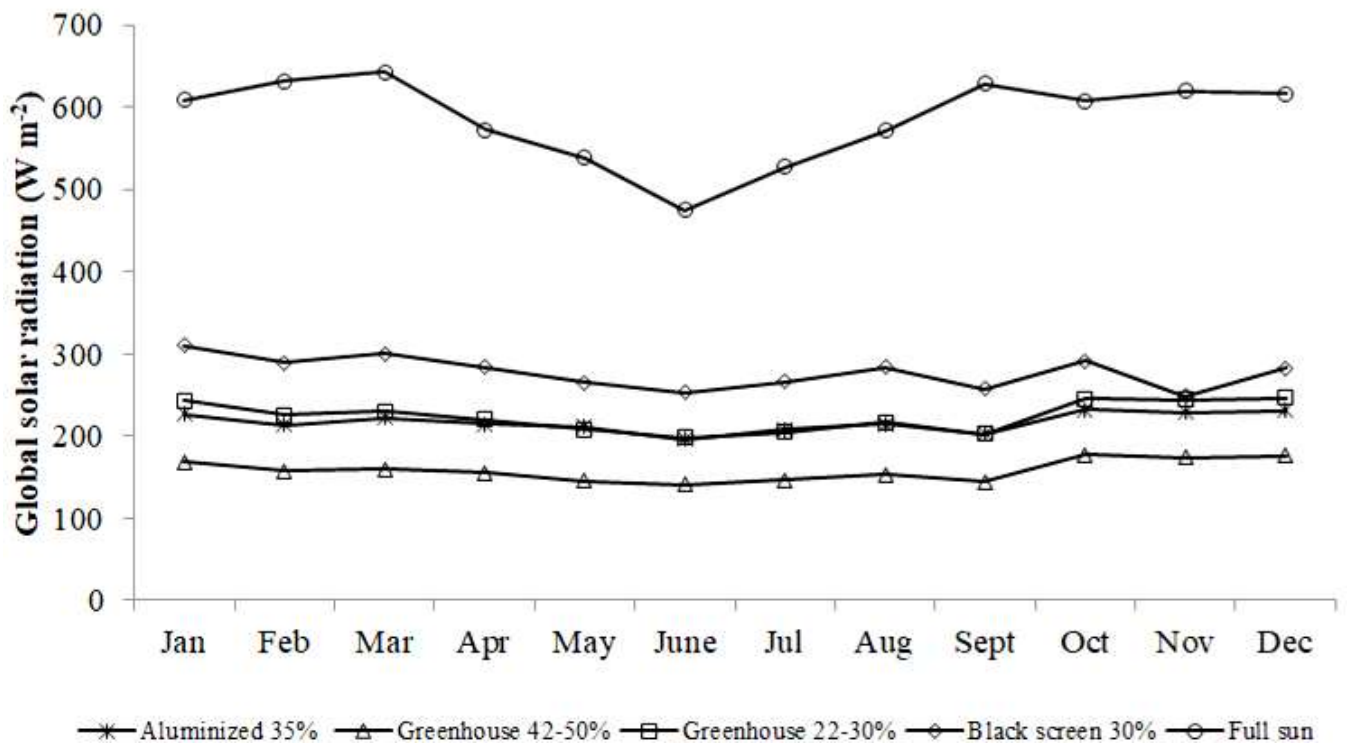

Figure 2. Monthly global solar radiation $\left(\mathrm{W} \mathrm{m}^{-2}\right)$ in protected and outdoor environments. 
Direct solar radiation can be favorable or harmful to plants depending on the species studied. For example, the yield of chives, Allium fistulosum, was higher in total sun cultivation than in a $100 \mu \mathrm{m}$ LDPE greenhouse (Silva et al., 2017). Another precaution when managing the plant environment in a protected environment is the effect of light stress on plants when changing from a more shaded environment to one with a higher level of solar radiation. This change can cause irreversible damage to plant morphology, and therefore, many producers of forest seedlings use a process called "rustification."

The shading level of the environments influenced the Global Solar Radiation (GSR). Thus, the greenhouse with a shading of $42-50 \%$ had the lowest radiation levels ( $157.86 \mathrm{~W} \mathrm{~m}^{-2}$ ), corresponding to $27 \%$ of the radiation of the external environment, which presented $586.41 \mathrm{Wm}^{-2}$. The Greenhouse environments with $22-30 \%$ shading screen, as well as the Aluminized Screen, with $35 \%$ shading described, showed an average of $37.5 \%$ of the solar radiation from the external environment and inside the screen with $30 \%$ shading, the available global radiation corresponded to $47 \%$ of the radiation from the external environment (Table 2, Figure 2).

These results show that the screens' shading value does not correspond to the GSR percentage inside the environment. In many papers in the literature, there is confusion between radiation, luminosity, and shading. The micrometeorological variables (temperature, humidity, and radiation) are correlated to express the best plant potential. For example, in a study with the effects of light and irrigation on forest species, water deficit promoted a lower growth rate in an environment with lower luminosity (Amissah et al., 2015).

In the test 2, air temperature, relative air humidity, and global solar radiation were influenced by the seasons of the year (S) and by the cultivation environments (E) in isolation, and both factors were highly significant (p-value $<0$.01) (Table 3 ). The noninteraction between factors (environments $\mathrm{x}$ seasons) verified for all variables studied (Table 3 ) shows that these factors are independent. This finding means that the environment behavior is independent of seasons' variation (absence or presence) and vice versa. Therefore, the study of factors separately is valid in this case (Perecin and Cargnelutti Filho, 2008).

It was observed in the micrometeorological variables that the types of environments, with their respective types of shading promoted by the different roofing materials and seasons of the year, were able to influence air temperature, relative humidity, and global solar radiation (Table 4) and were similar to what happened with the months of the year (Table 2).

Table 3. Analysis of variance with the significance of the $\mathrm{F}$ test for temperature $\left({ }^{\circ} \mathrm{C}\right)$, relative humidity $(\%)$, and global solar radiation $\left(\mathrm{W} \mathrm{m}^{-2}\right)$ in the environments and the seasons of the year.

\begin{tabular}{lccc}
\hline Source of Variation & $\mathrm{T}\left({ }^{\circ} \mathrm{C}\right)$ & $\mathrm{RH}(\%)$ & $\mathrm{GSR}\left(\mathrm{Wm}^{-2}\right)$ \\
\hline $\mathrm{S}$ & $* *$ & $* *$ & $* *$ \\
$\mathrm{E}$ & $* *$ & $* *$ & $\mathrm{~ns}$ \\
$\mathrm{~S} \mathrm{x} \mathrm{E}$ & $\mathrm{ns}$ & $\mathrm{ns}$ & 7.56 \\
$\mathrm{CV} 1$ & 4.60 & 8.30 & 14.84 \\
$\mathrm{CV} 2$ & 6.35 & 15.87 & \\
\hline
\end{tabular}

Coefficient of variation 1 relative to the parcels; Coefficient of Variation 2 relative to sub-plots. ** $=$ significant at $1 \%$; ns $=$ not significant; $\mathrm{S}=$ Seasons of the year; $\mathrm{E}=$ Environments.

Table 4. Air temperatures $\left({ }^{\circ} \mathrm{C}\right)$, relative air humidity $(\%)$ and global solar radiation $(\mathrm{W} \mathrm{m}-2)$ in environments and seasons

\begin{tabular}{lccc}
\hline Environments & Air Temperature & Relative Air Humidity & Global Solar Radiation $\left(\mathrm{W} \mathrm{m} \mathrm{m}^{-2}\right)$ \\
\hline Full sun & $24.81 \mathrm{~A}$ & $62.73 \mathrm{~B}$ & $586.23 \mathrm{~A}$ \\
Black screen 30\% & $24.57 \mathrm{~A}$ & $70.24 \mathrm{~A}$ & $279.04 \mathrm{~B}$ \\
Greenhouse + 22-30\% & $24.57 \mathrm{~A}$ & $68.13 \mathrm{~A}$ & $223.44 \mathrm{C}$ \\
Aluminized 35\% & $23.64 \mathrm{~B}$ & $68.30 \mathrm{~A}$ & $217.72 \mathrm{C}$ \\
Greenhouse + 42-50\% & $23.92 \mathrm{~B}$ & $68.83 \mathrm{~A}$ & $159.18 \mathrm{D}$ \\
\hline Seasons of the year & Air Temperature & Relative Air Humidity & Global Solar Radiation $\left(\mathrm{W} \mathrm{m}^{-2}\right)$ \\
\hline Spring & $25.39 \mathrm{~A}$ & $61.21 \mathrm{~B}$ & $312.82 \mathrm{~A}$ \\
Summer & $25.73 \mathrm{~A}$ & $76.36 \mathrm{~A}$ & $307.31 \mathrm{~A}$ \\
Autumn & $22.79 \mathrm{~B}$ & $73.92 \mathrm{~A}$ & $275.47 \mathrm{~B}$ \\
Winter & $23.29 \mathrm{~B}$ & $59.10 \mathrm{~B}$ & $276.88 \mathrm{~B}$ \\
\hline
\end{tabular}

Means in the same column for each variable, followed by equal letters, do not differ from each other, at the $1 \%$ level by the LSD test. 
For the seasons of the year, the micrometeorological variables of air temperature, the relative air humidity, and the global solar radiation in the environments (Table 4) had the same behavior observed for the experiment with the months of the year (Table 2).

In Brazil, the seasons are not as well-defined as in the Northern Hemisphere. Two distinct groups were formed for the micrometeorological variables with the seasons. The air temperature and global solar radiation in spring and summer $\left(25.56^{\circ} \mathrm{C} ; 310.07 \mathrm{~W} \mathrm{~m}-2\right)$ were higher than in autumn and winter $\left(23.04^{\circ} \mathrm{C} ; 276.18 .07\right.$ $\mathrm{W} \mathrm{m}-2)$. For relative air humidity, the distinct sets were summer and autumn $(75.14 \%)$ higher than winter and spring $(60.16 \%)$ (Table 4$)$.

These data show that the seasons of the study region, the Brazilian Midwest, are not well defined, resembling most areas close to the Equator and different from the Northern Hemisphere, as in the United States, with unambiguous seasons. This factor is explained by the non-existence of significant variations in solar radiation received, in these regions, throughout the year.

\section{Conclusions}

In the test, the shading intensity and the screen color interfered with the protected environments' air temperature: in greenhouses with screens under the film, the greater the shading, the lower the air temperature; in aluminized screens, the air temperature was lower than in black ones. All protected environments provided lower relative humidity than outdoors.

Solar radiation inside environments decreases depending on the type of environment and the type and shading level of the screens. The percentage of global solar radiation inside the environments, as a function of the outside, were as follows: full sun (100\%); black screen with $30 \%$ shading $(47.3 \%)$; greenhouse with LDPE + 22-30\% shading screen under the film (38.1\%); aluminized screen with $35 \%$ shading $(36.9 \%)$ and oven with LDPE $+42-50 \%$ shading screen under the film $(26.9 \%)$. There were no differences in global solar radiation in the $22-30 \%$ shading screen under the film and aluminized screen; however, the temperature was lower in the screen.

In the test 2, the micrometeorological conditions of air temperature, relative air humidity, and global solar radiation of the environments in the year's seasons are similar to the behavior verified in the monthly test.

Air temperatures and global solar radiation formed two distinct groups, with the spring and summer seasons being considered one group and autumn and winter as another group. The summer and autumn were the periods with the highest relative humidity in contrast to the winter and spring periods, with a low percentage of air humidity. Seasons in the study region are not as well defined as those in the northern hemisphere.

\section{Authors' Contribution}

Abimael Gomes da Silva contributed to setting up the experiment, collecting data, assisting in statistics, creating the figures, and writing the manuscript. Edilson Costa contributed to setting up the experiment, collecting data, collecting data, assisting in statistics, creating the figures, and writing the manuscript. Tiago Zoz contributed assisting in statistics, and writing the manuscript. Flávio Ferreira da Silva Binotti contributed assisting in statistics, and writing the manuscript.

\section{Acknowledgments}

To Foundation for Supporting the Development of Education, Science, and Technology of the State of Mato Grosso do Sul - FUNDECT (FUNDECT/CNPq/PRONEM - MS, Process 59/300.116/2015 - No. FUNDECT 080/2015). National Council for Scientific and Technological Development (CNPq).

\section{Bibliographic References}

Amissah, L., Mohren, G.M.J., Kyereh, B., Poorter, L. 2015. The effects of drought and shade on the performance, morphology and physiology of Ghanaian tree species. PLoS One, 10 (4): e0121004. http://doi.org/10.1371/journal.pone.0121004. (accessed 21 de Agosto de 2021).

Assis, F.N., Mendez, M.E.G. 1989. Relação entre radiação fotossinteticamente ativa e radiação global. Pesquisa $\begin{array}{llll}\text { Agropecuária } & \text { Brasileira, 24(7): }\end{array}$ http://seer.sct.embrapa.br/index.php/pab/article/view/15922. (acessado 3 de agosto de 2021)

Beckmann, M.Z., Duarte, G.R.B., Paula, V.A., Mendez, M.E.G., Peil, R.M.N. 2006. Radiação solar em ambiente protegido cultivado com tomateiro nas estações verão-outono do Rio Grande do Sul. Ciência Rural, 36(1), 86-92. https://doi.org/10.1590/S0103-84782006000100013. (acessado 3 de agosto de 2021).

Buriol, G.A., Streck, N.A., Schneider, F.M. 1993a. Modificação ambiental causada por túneis baixos de polietileno transparente perfurado cultivado com alface. Ciência Rural, 23(3): 261-266, https://www.scielo.br/j/cr/a/XN3B8YpvBWZwfZFs6NKTHfK/ ?format=pdf\&lang=en. (acessado 3 de Agosto de 2021).

Buriol, G.A., Righi, E.Z., Schneider, F.M.; Streck, N.A., Heldwein, A.B., Estefanel, V. 2000. Modificação da umidade relativa do ar pelo uso e manejo da estufa plástica. Revista Brasileira de Agrometeorologia, 8(1): 11-18, http://www.sbagro.org/files/biblioteca/1222.pdf. (acessado 4 de agosto de 2021).

Buriol, G.A., Schneider, F.M., Estefanel, V., Andriolo, J.L., Medeiros, S.L.P. 1993b. Modificação na temperatura mínima 
do ar causada por estufas de polietileno transparente de baixa densidade. Revista Brasileira de Agrometeorologia, 1(1), 4349. http://www.sbagro.org/files/biblioteca/14.pdf. (acessado 4 de agosto de 2021).

Buriol, G.A., Streck, N.A., Petry, C., Schneider, F.M. 1995. Transmissividade da radiação solar do polietileno de baixa densidade utilizado em estufas. Ciência Rural, 25(1), 1-4. DOI: http://doi.org/10.1590/S0103-84781995000100001. (acessado 4 de agosto de 2021).

Camacho, J.M., Assis, F.N., Martins, S.R., Mendez, M.E.G. 1995. Avaliação de elementos meteorológicos em estufa plástica em Pelotas. Revista Brasileira de Agrometeorologia, Santa Maria, 3(1): 19-24. http://www.sbagro.org/files/biblioteca/51.pdf. (acessado 3 de agosto de 2021).

Cardoso, L.S. Bergamaschi, H., Comiran, F., Chavarria, G., Marodin, G.A.B., Dalmago, G.A., Santos, H.P., Mandelli, F. 2008. Alterações micrometeorológicas em vinhedos pelo uso de coberturas de plástico. Pesquisa Agropecuária Brasileira, 43(4):441-447 https://seer.sct.embrapa.br/index.php/pab/article/view/165. (acessado 4 de agosto de 2021).

Costa, E., Martins, M.B., Vedruscolo, E.P., Silva, A.G., Zoz, T., Binotti, F.F.S., Witt, T.W., Seron, C.C. 2020. Greenhouses within the Agricultura 4.0 interface. Revista Ciência Agronômica 51(5): e20207703. http://ccarevista.ufc.br/seer/index.php/ccarevista/article/view/7 703. (acessed August 4, 2021).

Costa, E., Leal, P.A.M. 2011. Medidas radiométricas em casas de vegetação com cobertura plástica na região de Campinas SP. Engenharia Agrícola, 31(3): 448-457. DOI: http://doi.org/10.1590/S0100-69162011000300005. (acessado 4 de agosto de 2021).

Costa, E., Leal, P.A.M., Carmo Júnior, R.R. 2004. Modelo de simulação da temperatura e umidade relativa do ar no interior de estufa plástica. Engenharia Agrícola, 24(1), 57-67. DOI: http://doi.org/10.1590/S0100-69162004000100008. (acessado 4 de agosto de2021).

Cunha, A.R., Escobedo, J.F. 2003. Alterações micrometeorológicas causadas pela estufa plástica e seus efeitos no crescimento e produção da cultura do pimentão. Revista Brasileira de Agrometeorologia, 11(1): 15-26, http://www.sbagro.org/files/biblioteca/1353.pdf. (acessado 4 de agosto de 21).

Cunha, A.R., Escobedo, J.F., Klosowski, E.S. 2002. Estimativa do fluxo de calor latente pelo balanço de energia em cultivo protegido de pimentão. Pesquisa Agropecuária Brasileira, 37(6): 735-743. DOI: http://dx.doi.org/10.1590/S0100-204X2002000600001. (acessado 4 de agosto de 2021).

Cunha, A.R., Escobedo, J.F. Klosowski, E.S. 2001. Balanço de energia em pimenteiro sob cultivo $\mathrm{p} / /$ rotegido e a campo. Revista Brasileira de Agrometeorologia, 9(2), 159-167. http: sbagro.org/files/biblioteca/1282.pdf. (acessado 3 de agosto de 2021).

Duarte, L.A, Schöffel, E.R, Mendez, M.E.G, Schallenberger, E. 2011. Alterações na temperatura do ar mediante telas nas laterais de ambientes protegidos cultivados com tomateiro. Revista Brasileira de Engenharia Agrícola e Ambiental, 15(2): 148-153. DOI: http://doi.org/10.1590/S141543662011000200006. (acessado 4 de agosto de 2021).

Farias, J.R.B., Bergamaschi, H., Martins, S.R., Berlato, M.A. 1993a. Efeito da cobertura plástica de estufa sobre a radiação solar. Revista Brasileira de Agrometeorologia, 1(1), 31-36. http://www.sbagro.org/files/biblioteca/12.pdf. (acessado $23 \mathrm{de}$ agosto de 2021).

Farias, J.R.B., Bergamaschi, H., Martins, S.R., Berlato, M.A., Oliveira, A.C.B. 1993b. Alterações na temperatura e umidade relativa do ar provocadas pelo uso de estufa plástica. Revista Brasileira de Agrometeorologia, 1(1): 51-62. http://www.sbagro.org/files/biblioteca/15.pdf. (acessado 23 de agosto de 2021).

Ferrari, D.L., Leal, PA.M. 2015. Uso de tela termorrefletora em ambientes protegidos para cultivo do tomateiro. Engenharia Agrícola, 35(2), 180-191. DOI: https://doi.org/10.1590/1809-4430-Eng.Agric.v35n2p180-

191/2015. (acessado 4 de agosto de 2021).

França, S., Rosa, L.M.G., Bergamaschi, H., Nabinger, C., Spanennberg, P. 1997. Radiação fotossinteticamente ativa e sua relação com a radiação solar global em dossel de alfafa, em função do índice de área foliar. Revista Brasileira de Agrometeorologia, 5(2): 147-153. http://sbagro.org/files/biblioteca/132.pdf. (acessado 21 de agosto de 2021).

Frisina, V.A., Escobedo, J.F. 1999. Radiation and energy balance of lettuce culture inside a polyethylene greenhouse. Pesquisa Agropecuária Brasileira, 34(10), 1775- 1786. DOI: http://dx.doi.org/10.1590/S0100204X1999001000003. (acessed August 3, 2021).

Furlan, R.A., Folegatti, M.V. 2002. Distribuição vertical e horizontal de temperaturas do ar em ambientes protegidos. Revista Brasileira de Engenharia Agrícola e Ambiental, 6(1), 93100. DOI: http://doi.org/10.1590/S1415-43662002000100017. (acessado 4 de agosto de 2021).

Galvani, E., Escobedo, J.F. 2001. Balanço de energia na cultura de pepineiro em ambiente natural e protegido. Bragantia, 60(2), 127-137. http://doi.org/10.1590/S0006-87052001000200009. (acessado 4 de agosto de 2021).

Galvani, E., Escobedo, J.F., Pereira, A.B. 2001. Balanço de radiação e fluxo de calor no solo em ambiente natural e protegido cultivado com pepineiro. Bragantia, 60(2), 139-147. DOI: https://dx.doi.org/10.1590/S0006-87052001000200010. (acessado 4 de agosto de 2021).

Guiselini C., Sentelhas P.C. 2004. Uso de malhas de sombreamento em ambiente protegido I: Efeito na temperatura e na umidade do ar. Revista Brasileira de Agrometeorologia, 12(1): 9-17. http://www.sbagro.org/files/biblioteca/1406.pdf. (acessado 4 de agosto de 2021).

Guiselini, C., Sentelhas, P.C., Oliveira, R.C. 2004b. Uso de malhas de sombreamento em ambiente protegido II: Efeito na radiação solar global e fotossinteticamente ativa. Revista Brasileira de Agrometeorologia, 12(1), 19-26, http://sbagro.org/files/biblioteca/1405.pdf. (acessado 4 de agosto de 2021). 
Guiselini, C., Sentelhas, P.C., Oliveira, R.C., Prela, A. 2004a. Uso de malhas de sombreamento em ambiente protegido III: Efeito sobre o crescimento e a produção comercial da Gerbera jamesonii. Revista Brasileira de Agrometeorologia, 12(1), 2734, http://www.sbagro.org/files/biblioteca/1407.pdf. (acessado 4 de agosto de 2021).

Guiselini, C., Sentelhas, P.C., Pandorfi, H., Holcman E. 2010. Manejo da cobertura de ambientes protegidos: radiação solar e seus efeitos na produção da gérbera. Revista Brasileira de Engenharia Agrícola e Ambiental, 14(6), 645-652. DOI: http://doi.org/10.1590/S1415-43662010000600011. (acessado 4 de agosto de 2021).

Lulu, J., Pedro Júnior, M.J. 2006. Microclima de vinhedos cultivados sob cobertura plástica e a céu aberto. Revista Brasileira de Agrometeorologia, 14(1), 106-115. http://www.sbagro.org/files/biblioteca/3945.pdf. (acessado 21 de agosto de 2021).

Morais, H., Caramori, P.H., Koguishi, M.S., Ribeiro, A.M.A. 2007. Caracterização microclimática de cafeeiros cultivados sob malha de sombreamento e a pleno sol. Revista Brasileira de Agrometeorologia, 15(2), 133-42. http://www.sbagro.org/files/biblioteca/3988.pdf. (acessado 4 de agosto de 2021).

Paula, R.C.M., Silva, A.G., Costa, E., Binotti. F.F.S. 2017. Monitoramento de variáveis micrometeorológicas em diferentes ambientes protegidos no período de inverno. Revista de Agricultura Neotropical, 4(5), 2017. DOI: http://doi.org/10.32404/rean.v4i5.2210. (acessado 4 de agosto de 2021).

Perecin, D., Cargnelutti Filho, A. 2008. Efeitos por comparações e por experimento em interações de experimentos fatoriais. Ciência e Agrotecnologia, 32(1), 6872. DOI: http://doi.org/10.1590/S1413-70542008000100010. (acessado 4 de agosto de 2021).

Radin, B., Bergamaschi, H., Reisser Junior, C., Barni, N.A., Matzenauer, R. 2003. Eficiência de uso da radiação fotossinteticamente ativa pela cultura do tomateiro em diferentes ambientes. Pesquisa Agropecuária Brasileira, 38(9): 1017-1023. DOI: $\quad$ http://doi.org/10.1590/S0100-204X2003000900001. (acessado 4 de agosto de 2021).

Rampazzo, R., Seabra Junior, S., Nunes, M.C.M., Neves, S.M.A.S., Ferreira, R.F. 2014. Eficiência de telas termorefletoras e de sombreamento em ambiente protegido tipo telado sob temperaturas elevadas. Engenharia na Agricultura, 22(1), 33-42. http://doi.org/10.13083/reveng.v22i1.362. (acessado 4 de agosto de 2021).

Rebouças, P.M., Dias, I.F., Alves, M.A., Barbosa Filho, J.A.D. 2015. Radiação solar e temperatura do ar em ambiente protegido. Revista Agrogeoambiental, 7(2), 115-125. DOI: http://dx.doi.org/10.18406/2316-1817v7n22015610. (acessado 4 de agosto de 2021).

Reis, L.S., Souza, J.L., Azevedo, C.A.V., Lyra, G.B., Ferreira Junior, R.A., Lima, V.L. A. 2012. Componentes da radiação solar em cultivo de tomate sob condições de ambiente protegido. Revista Brasileira de Engenharia Agrícola e Ambiental,
16(7), 739-744. http://www.agriambi.com.br/revista/v16n07/ v16n07a06.pdf. (acessado 4 de agosto de 2021).

Reisser Júnior, C., Bergamaschi, H., Radin, B., Bergonci, J.I. 2003. Alterações morfológicas do tomateiro em resposta à redução de radiação solar em ambientes de estufa plástica. Revista Brasileira de Agrometeorologia, 11(1),7-14, http://www.sbagro.org/files/biblioteca/1352.pdf. (acessado 4 de agosto de 2021).

Sales, F.A.L., Barbosa Filho, J.A.D. Barbosa, J.P.R.A.D., Viana, T.V.A., Freitas, C.A.S. 2014. Telas agrícolas como subcobertura no cultivo de alface hidropônica. Ciência Rural, 44(10), 1755-1760. DOI: http://doi.org/10.1590/01038478cr20120633. (acessado 4 de agosto de 2021).

Santos, L.L., Seabra Junior, S., Nunes, M.C.M. 2010. Luminosidade, temperatura do ar e do solo em ambientes de cultivo protegido. Revista de Ciências AgroAmbientais, Alta Floresta, 8(1), 83-93. http://www.unemat.br/revistas/rcaa/docs/vol8/8_artigo_v8.pdf (acessado 4 de agosto de 2021).

Scaranari, C., Leal, P.A.M., Pellegrino, G.Q. 2008. Estudo de simulações de microclimas em casas de vegetação visando à aclimatação de mudas micropropagadas de bananeira cv Grande Naine. Revista Brasileira de Fruticultura, 30(4), 1001-1008. DOI: $\quad$ https://doi.org/10.1590/S0100-29452008000400027. (acessado 4 de agosto de 2021).

Sentelhas, P.C., Borsatto, R.S., Minami, K. 1999. Transmissividade da radiação solar em estufas cobertas com filmes de PVC azul e transparente. Revista Brasileira de Agrometeorologia, 7(2),157-162. http://www.leb.esalq.usp.br/agmfacil/artigos/artigos_sentelhas _1999/1999_RBAgro_7(2)_157-162_TransmRadPVC.pdf. (acessado 23 de agosto de 2021).

Sentelhas, P.C., Santos, A.O. 1995. Cultivo Protegido: Aspectos microclimáticos. Revista Brasileira de Horticultura Ornamental, 1(1), 108-115. http://ornamentalhorticulture.emnuvens.com.br/rbho/article/vi ewFile/99/1733. (acessado 3 de agosto de 2021).

Sentelhas, P.C., Villa Nova, N.A., Angelocci, L.R. 1998. Efeito de diferentes tipos de cobertura, em mini-estufas, na atenuação da radiação solar e da luminosidade. Revista Brasileira de Agrometeorologia, 6(1), 479-481. http://www.sbagro.org/files/biblioteca/4668.pdf. (acessado 23 de agosto de 2021)

Schneider, F.M., Buriol, G.A., Andriolo, J.L., Estefanel, V., Streck, N.A. 1993. Modificação na temperature do solo causada por estufa de polietileno transparente de baixa densidade em Santa Maria, RS. Revista Brasileira de Agrometeorologia, 1(1), 37-42. http://www.sbagro.org/files/biblioteca/13.pdf. (acessado $21 \mathrm{de}$ agosto de 2021).

Silva, B.L.B., Costa, E., Binotti, F.F.S., Benett, C.G.S., Silva, A.G. 2018. Growth and quality of Garcinia humilis seedlings as a function of substrate and shading level. Pesquisa Agropecuária Tropical, 48(4), 407-413. DOI: https://dx.doi.org/10.1590/1983-40632018v4853500. (acessed August 3, 2021). 
Silva, D.F., Araújo Neto, S.E., Ferreira, R.L.F., Ribeiro, S.A.L., Silva, R.S., Silva, N.M. 2017. Controle alternativo da antracnose em cebolinha orgânica cultivada em ambiente protegido e campo. ACSA, 13 (3), 223-228. http://revistas.ufcg.edu.br/acsa/index.php/ACSA/article/view/ 889/pdf. (acessado 4 de agosto de 2021).

Silva, E.T., Byllardt, L.V.B., Gomes, S., Wolf, G.D. 2003. Comportamento da temperatura do ar sob condições de cultivo em ambiente protegido. Revista Acadêmica: ciências agrárias e ambientais, 1(1), 51-54. https://periodicos.pucpr.br/index.php/cienciaanimal/article/vie w/14886. (acessado 4 de agosto de 2021).

Sousa, J.W., Martins, D., Cunha, A.R., Escobedo, J.F., Galvani, E. 2005. Alterações do saldo de radiação, temperatura e umidade relativa do ar em ambiente protegido com cobertura de polietileno difusor de luz. Revista Brasileira de Agrometeorologia, 13(1):110, http://www.sbagro.org/files/biblioteca/1442.pdf. (acessado 4 de agosto de 2021).

Souza, J.L., Escobedo, J. F. 1997. Balanço de radiação em cultivos de feijão-vagem com e sem cobertura de polietileno. Pesquisa Agropecuária Brasileira, 32(1):1-15. http://seer.sct.embrapa.br/index.php/pab/article/view/4600. (acessado 4 de agosto de 2021).

Souza, J.L., Escobedo, J. F., Tornero, M. T. 1999. Albedo e estimativas do saldo de radiação em feijão-vagem sob cobertura de plástico e ambiente externo. Pesquisa Agropecuária Brasileira, 34(10): 1763-1774, http://www.scielo.br/j/pab/a/xFcbVh4dzzmLbwKLthVGhgk/a bstract/?lang=en. (acessado 4 de agosto de 2021).

Steidle Neto, A.J., Zolnier, S., Marouelli, W.A., Carrijo, O.A. 2008. Razão entre radiação fotossinteticamente ativa e radiação global no cultivo do tomateiro em casa-devegetação. Revista Brasileira de Engenharia Agrícola e Ambiental, 12(6): 626-631. DOI: http://doi.org/10.1590/S1415-43662008000600009. (acessado 4 de agosto de 2021).

Vásquez, M. A. N., Folegatti, M. V., Dias, N. S., Silva, C. R. 2005. Efeito do ambiente protegido cultivado com melão sobre os elementos meteorológicos e sua relação com as condições externas. Engenharia Agrícola, 25(1): 137-143. DOI: https://dx.doi.org/10.1590/S0100-69162005000100015. (acessado 4 de agosto de2021). 